\title{
DEVELOPING AN IMPROVEMENT STRATEGY IN HEALTH RESEARCH INNOVATION AND QUALITY BASED ON TECHNOLOGY WATCH ADOPTION: A CUBAN CASE STUDY
}

\author{
DESENVOLVIMENTO DE UMA ESTRATÉGIA PARA MELHORAR A CIÊNCIA, INOVAÇ̃O \\ E QUALIDADE EM SAÚDE A PARTIR DA ADOPÇÃO DA VIGILÂNCIA TECNOLÓGICA: UM \\ CASO CUBANO
}

\begin{abstract}
DESARROLLO DE UNA ESTRATEGIA DE MEJORA DE LA CIENCIA LA INNOVACIÓN Y LA CALIDAD EN SALUD BASADO EN LA VIGILANCIA TECNOLÓGICA: UN CASO CUBANO
\end{abstract}

\author{
iD Arialys Hernández Nariño ${ }^{1}$ \\ (iD) Neyfe Sablón Cossío ${ }^{2}$ \\ iD Guillermo Ramos Castro ${ }^{3}$ \\ Adalberto Hernández Castro ${ }^{4}$
}

Cite as - American Psychological Association (APA)

Nariño, A. H., Cossío, N. S., Castro, G. R., \& Castro, A. H. (2021, Jan./Apr.). Developing an improvement strategy in health research innovation and quality based on technology watch adoption: a cuban case study. International Journal of Innovation - IJI, São Paulo, 9(1), 11-44. https://doi.org/10.5585/iji.v9i1.18103.

\begin{abstract}
Objective: To develop an improvement strategy on research, innovation and quality of health, based on technology watch adoption.

Method: A non experimental study that comprehends descriptive and bibliometric analysis was used, along with the implementation of technology watch procedure to support the strategy.

Originality/Relevance: Technology watch along with strategic intelligence are acknowledged to be key tools in innovation processes as well as in strengthening National Science Technology and Innovation Systems (Guagliano, Villanueva, Perez and Sánchez Rico, 2019); its use has spread to numerous public and private companies, government agencies, consulting institutions, universities and research centers which are being interested in anticipating the continous and emerging challenges from the changing environment and hence making proper strategic decisions (Guagliano, Massaro and Rodríguez Bianchi, 2015); particularly in health care its applications are extended to technology assessment, care services improvement and academic research capacity planning and strengthening (Carrillo Zambrano, Páez Leal, Suárez and Luna-González, 2018). Specifically, Research, Quality and Innovation management at a local health system in Cuba, needs to generate high value-added information and knowledge to enhance performance and accurate decision making.

Results: Here we show how the development of technology watch enhance and support the formulation of research, development and innovation projects; and standardization of healthcare services and processes, which were selected as relevant variables in a previous prospective study.

\footnotetext{
1 Industrial engineer, PhD. Universidad de Ciencias Médicas de Matanzas, Universidad de Matanzas, Cuba. arialishn.mtz@infomed.sld.cu

2 Industrial engineer, PhD. Universidad Técnica de Manabí, Manabí, Ecuador. nsabloncossio@gmail.com

${ }^{3}$ Industrial engineer, MSc. Universidad de Ciencias Médicas de Matanzas, Cuba. gramos.mtz@infomed.sld.cu

${ }^{4}$ Industrial engineer, MSc. Clínica Avendaño, Perú. acastro@clinicaavendaanoperu.com
} 
Social / management contributions: The results are aligned with the Cuban healthcare strategic goals, for among its current demands, it prioritizes the generation of high-impact scientific and innovative results, as well as the development of a quality strategy that portrays, among its core objectives, health services continuous improvement, based on developing standards, Clinical Practice Guidelines and therapeutic protocols.

Theoretical/Methodological contributions: The adoption of Technology and Innovation management and knowledge-based techniques may offer valuable benefits within research and quality of healthcare context.

Keywords: Technology watch. Innovation. Quality management. R\&D projects. Healthcare.

\section{Resumo}

Objectivo: desenvolver uma estratégia para melhorar a ciência, inovação e qualidade em saúde a partir da adopção de vigilância tecnológica.

Método: Foi desenvolvida uma pesquisa não experimental que incluiu análises descritivas e bibliométricos integrados à aplicação de um procedimento de vigilância tecnológica.

Originalidade / Relevância: A Vigilância Tecnológica e a Inteligência Estratégica são reconhecidas como ferramentas fundamentais nos processos de inovação, bem como no fortalecimento dos Sistemas Nacionais de Ciência, Tecnologia e Inovação (Guagliano, Villanueva, Perez and Sánchez Rico, 2019). Seu uso foi estendido a várias empresas públicas e privadas, agências governamentais, organizações de consultoria, universidades e centros de pesquisa que precisam se antecipar aos desafios contínuos e emergentes desafios do ambiente em mudança, para consequentemente tomar decisões estratégicas (Guagliano, Massaro and Rodríguez Bianchi, 2015). Particularmente, no sector da saúde, suas aplicações têm incluído a avaliação de tecnologias, a melhoria dos serviços de saúde, o planeamento e o aprimoramento da pesquisa e da capacidade académica (Carrillo Zambrano, Páez Leal, Suárez and Luna-González, 2018). O sistema de ciência e inovação de um sistema territorial de saúde em Cuba requer a geração de informação e conhecimento de alto valor agregado para potencializar o desempenho deste sistema e tomar decisões oportunas.

Resultados: Mostra-se como a aplicação de ferramentas de vigilância tecnológica permite aprimorar e apoiar a formulação de projectos de investigação, desenvolvimento e inovação; e a protocolização dos serviços e processos de saúde, em alinhamento com as duas variáveis estratégicas seleccionadas em estudo prospectivo precedente.

Contribuições sociais / gerências: Os resultados estão alinhados aos objectivos estratégicos da saúde pública em Cuba, pois entre suas demandas actuais prioriza a geração de resultados técnico-científicos de alto impacto, com capacidade de se tornarem inovadores; bem como o desenvolvimento de uma estratégia de qualidade que traça a melhoria contínua entre os seus objectivos estratégicos, com base no desenvolvimento de normas, Normas de Prática Clínica (NPC) e protocolos de acção.

Contribuições teóricas - metodológicas: A gestão da tecnologia e inovação integrada em técnicas baseadas no monitoramento do meio ambiente, a gestão da informação e do conhecimento pode oferecer benefícios valiosos no contexto da pesquisa e da qualidade em saúde.

Palabras-chave: Vigilância tecnológica. Inovação. Gestão da qualidade. Projectos de investigação. Saúde.

\section{Resumen}

Objetivo: desarrollar una estrategia de mejora de la ciencia, la innovación y la calidad en salud basada en la adopción de la vigilancia tecnológica

Método: Se desarrolló una investigación no experimental que comprendió análisis descriptivos y bibliométricos integrados a la aplicación de un procedimiento de vigilancia tecnológica

Originalidad/Relevancia: La Vigilancia Tecnológica y la Inteligencia Estratégica se reconocen como herramientas clave en los procesos de innovación asi como en el fortalecimiento de los Sistemas Nacionales de Ciencia Tecnologia e Innovación (Guagliano, Villanueva, Perez and Sánchez Rico, 2019); su utilización se ha extendido a diversas empresas publicas y priuvadas, agencias gubernamentales, organizaciones de consultoría, universidades y centros de investigación que necesitan 
anticiparse a continuos y emergentes retos del entorno cambiante, para consecuentemente, tomar decisiones estratégicas (Guagliano, Massaro and Rodríguez Bianchi, 2015). Particularmente, en el sector de la salud sus aplicaciones han abarcado la evaluacion de tecnologias, mejoramiento de servicios de salud, planificación y perfeccionamiento de capacidades investigativas y académicas (Carrillo Zambrano, Páez Leal, Suárez and Luna-González, 2018). Por su parte, el sistema de ciencia e innovación de un sistema territorial de salud en Cuba, precisa de la generación de información y conocimiento de alto valor agregado para potenciar el desempeño de este sistema y la toma de decisiones oportuna.

Resultados: Se muestra como la aplicación de herramientas de vigilancia tecnológica permiten perfeccionar y apoyar la formulación de proyectos de investigación, desarrollo e innovación; y la protocolización de servicios y procesos asistenciales, en alineación a las dos variables estrategicas seleccionadas en un studio prospectivo precedente.

Contibuciones sociales/gerenciales: Los resultados están alineados con los objetivos estratégicos de la salud pública en Cuba, pues entre sus demandas actuales, prioriza la generación de resultados científicotécnicos de alto impacto, con capacidad de convertirse en innovaciones; así como el desarrollo de una estrategia de calidad que delinea entre sus objetivos estratégicos el perfeccionamiento continuo, basado en desarrollar normas, Guías de Práctica Clínica (GPC) y protocolos de actuación.

Contibuciones teóricas/metodológicas: La gestión de la tecnología y la innovación integrada a técnicas basadas en el monitoreo del entorno, la gestion de la información y del conocimiento puede ofrecer valiosos beneficios en el contexto de la investigación y la calidad en salud.

Palabras-clave: Vigilancia tecnológica. Innovación. Gestión de la calidad. Proyectos de investigación. Salud.

\section{Introduction}

National Research and Innovation in Cuba is regulated by the Ministry of Science, Technology and Environment by means of a legal framework that is gradually enhancing and upgrading the organization of research and innovation process across all econonomic and scientific institutions (Resolución 287, 2019).

Aproximately $26 \%$ of those organizations are devoted to health research, development and innovation. National Health Research and Innovation System (NHRIS) is composed of a network of primary, secondary and tertiary health services, research and training institutions, and that reveals a distintive feature, which is the interrelation between care services, research and training making it a unique and integral system (Rojo Pérez, Valentti Pérez, Martínez Trujillo, Morales Suárez, Martínez Torres, Fleitas Estéves, Portuondo Sao, M., Torres Rojo and Sierra González, 2018).

Then technological innovation process in health care is argued to be preceded by research of social and economical needs (Pérez Sánchez, Paredes Esponda, León Rodríguez and Pérez de Hoz, 2017).

Its development is based on three dimensions: stakeholders (technological institutions and universities); methological requirements stated by The Ministry of Public Health, which establish: an assessment question, objective, evidence sistematic searching criteria, evidence 
analysis and synthesis, results discussion report, dissemination, implementation and appraissal (Toledo Hernández, Portuondo Sao, Morales del Rosario, Norabuena Canal and Mejías Sánchez, 2016); and subsystems in which it is structured. These subsystems are research, development programs and projects, results introduction, integration interfaces, intelectual property and quality of health; the latter has been modeled by a national strategy (Ministerio de Salud Pública, 2016), whose main objectives are:

1. To continuosly improve health service quality by means of legal rules, standards, clinical practice guidelines and therapeutic protocols.

2. To foster health care accreditation, focused on three components: patient safety and care, hospital safety and management, and research and learning (Colectivo de autores, 2016).

The relevance of Health care in Cuba is also revealed by its economic and social importance, as confirmed in The Guidelines for the Economic and Social Policy whereby it is stated the need to foster innovation, quality and human capital training, in order to face health problems, care delivery issues and technological constraints limiting the sector's proper development (Comité Central del PCC, 2017).

Numerous facts, showed in different references, support the guidelines outlined in the aforementioned Guidelines for the Economic and Social Policy; for example Hernández Betancourt (2015) they state that it is a pressing need to speed up the implementation of quality management systems, which can guarantee and support health care services, providing them with credibility, efficiency, dependability, scientific rigor and safety, thus guaranteeing a continuous and upward increase from the patient's fulfillment; while Rojo Pérez et al. (2018) they consider as basic challenges to strengthen research competences, to generate more impact published articles and patents, as a way to validate high level scientific results. This indicates that quality, innovation and research are two strategic goals for the Cuban health care system

Nowadays improving the quality of care is gradually relying on the uses of data, information and knowledge to support clinical decisions (Hoffmann, Stichele, Bates, Björklund, Alexander, Andersson, Auraaen, Bennie, Dahl, Eiermann, Hackl, Hammar, Hjemdahl, Koch, Kunnamo, Le Louët, Panagiotis, Rägo, Spedding, Seidling, DemnerFushman, and Gustafsson., 2020) and even on applying the whole methodology of technology watch (Barreneche, García, Serrano, Brand and Hernández, 2015).

Health care systems around the world have been recommending the use of protocols and Clinical Practice Guidelines to improve decision making and deliver safe and effective care 
(Elías Dib, 2009). As a result indicator of quality of service, protocols use in clinical practice have spread around the world (Torres Andrade, Alarcón, Berthet, Cantero, Llanquipichún, Sáez and Yáñez., 2016). They contain directions to diagnosis, prevention and treatment of certain diseases; its design is conditioned by health problem definition and research statement and it is based on the principle of providing scientifc validity to the standardization of clinical and care processes (Artalejo and Ortún Rubio, 1990; Torres Andrade et al., 2016). Clinical Practice Guidelines (CPG) are as well commonly used as quality standardiation instrument in clinical environments; for Hou, Li, He, Wang, Yan, Han, Li, Cao, Zhou, Lu, Jia, Li, Hui and Li (2019) evidence-based guidelines are expected to provide clinicians with explicit recommendations on how to manage health conditions and bridge the gap between research and clinical practice.

On the other hand, Research development and innovation (R\&D\&i) management is acknowledged to involve planning, directing, controlling and coordinating the development and implementation of R\&D\&i capabilities in order to shape and accomplish the strategic and operational objectives of organizations (Cetindamar, Phaal and Probert, 2009); hence it includes the management of basic research, applied research, and experimental development (Organisation for Economic Co-operation and Development, 2015); which is methodologically organized and structured into a Project. Research and development and innovation (R\&D\&i) projects design is increasingly challenging in knowledge-based organizations as it needs to involve many variables: technological, social and economical, culture, laws and policies, knowledge generation frameworks, world trends among others. The coordinated and structured interaction between all these elements is aided by tools like Technology Watch, Competitive Intelligence and Foresight, because they can provide a fundamental basis for capacity and competitive advantages (Aguirre Ramirez, Cataño Rojas and Rojas López, 2013).

According to Gaínza (2006) R\&D projects’ main content is associated to links between science technology and innovation priorities and the problem identified, relevant information searching about products or strategic technologies, as well as bibliography analysis for state of art formulation. All those activities are supported by technology watch actions; this statement is similar to that of García Delgado, Delgado Fernández and Infante Abreu (2014) who report several proposals adopting technology watch as a support tool to R\&D projects development.

Technology Watch Systems can be defined as compilers of information that are in charge of obtaining and processing all knowledge that might be of interest for an organization (Gaviria Roa, Hernández Martínez and Montiel Ariza, 2019). 
Alfonso Sánchez and Ponjuán Dante (2016) refer that an efective use of information allows higher levels of quality in teaching, research, innovation and medical care; this last setting is gradually favoured by information and communication technologies beign used mainly in diagnosis, therapeutics, clinical care, management and epidemiology.

In fact, Technology Watch and related tools like Competitive Intelligence or information and knowledge based techniques, have been comprehensively adopted by different health related issues such as: proving effectiveness and viability of innovations and technological development of new biofarmaceutical products (Guagliano, Tornillo, Pascal, \& Massaro, 2017; Vargas, Duque Beltrán, Arévalo Jamaica and Quintero Vargas, 2018) scientific evidence searching and adoption of propper clinical guidelines and protocols aiming to reduce adverse effects or consecuences (van der Veer, Jager, Nache, Richardson, Hegarty, Couchoud, de Keizer and Tomson, 2011) hospital service improvement (Barreneche et al., 2015); and research development and prioritization (Carrillo Zambrano et al., 2018; Luque Clavijo, Sepulveda Carrillo and Cano Urrego, 2011).

The advantages afforded by technology watch to monitor the environment, the information and knowledge adquisition and processing, would certainly favor decision making, and to design improvement strategies in areas which are considered a challenge for the Cuban Health care system such as the increase on the quality and quantity of I\&D\&I projects; generating and introducing high value research results, which may increase the quality of health services. These two challenges are conditioned by difficulties on the sistematic uses of information and knowledge that supports the scientific innovation, topicality and correspondence among projects and investigation research lines, trends, novel technologies and high value scientific evidence whereas the development of impact innovations (Hernández Nariño, López Álvarez, Castro Hernández, \& Ponce de León Narváez, 2019).

Consequently, the outcome of this work is to implement an improvement strategy on research, innovation and quality of health, based on technology watch adoption.

\section{Brief theoretical framework}

\subsection{Research, tecnology and innovation}

Research development and innovation (R\&D\&i) management involves planning, directing, controlling and coordinating the development and implementation of R\&D\&i capabilities in order to shape and accomplish the strategic and operational objectives of organizations (Cetindamar et al., 2009). According to the Frascati manual, R\&D\&i 
management includes the management of basic research, applied research, and experimental development (Organisation for Economic Co-operation and Development, 2015).

According to Arciénaga Morales, Nielsen, Bacarini, Martinelli, Kofuji and García Díaz (2018) technology and innovation management comprehends a logical or heuristic sequence of the decision-making process: gathering of information; prospective, technology surveillance, and competitive intelligence; evaluating and devising strategic solution based on problems and opportunities; executing concrete actions to obtain such solutions such as new product development, R\&D management, commercialization (including introduction of new products), intellectual property protection, technology-based entrepreneurship, input management, knowledge management, project, internal process and product management, and technological innovation; and financing all the above activities.

Cerezo Narváez, García Jurado, González Cruz, Pastor Fernández, Otero Mateo and Ballesteros Pérez (2019), based on literature review, stated that R\&D\&i, in any of its conceptions, has a positive effect on the performance of organizations, and this idea is supported by the following arguments extrated from authors statements: innovation is one of the key factors for companies long-term success; the development of technological innovations favours the introduction of improvements in the organizational management context, and also quicker knowledge, learning and exchange; companies with the ability to innovate face and resolve challenges and conflicts quicker than non-innovative ones.

Mardani, Nikoosokhan, Moradi and Doustar (2018) summarize the view of several researchers about the relation between organizational innovation and knowledge. Pespectives analysed arouse the following concept: innovation is the combination of a firm's existing knowledge assets to create new knowledge, then, the primary task of the innovating firm is to reconfigure existing knowledge assets and resources, and to examine new knowledge; empirical case study evidence shows mixed results whereby on one hand it is confirmed the positive role of knowledge dissemination on innovation success, while on the other it is not found any significant effect; different types of innovation are affected by Knowledge Management (KM), as they require different resources and hence a differentiated KM strategy. Authors conclude that effective $\mathrm{KM}$ as presented in the literature, is a method for improving innovation and performance. Based on the summary of Arciénaga Morales et al. (2018), R\&D, KM and strategy approach are commonly included by authors in innovation management.

As for technology and $\mathrm{KM}$ it is assumed a strong relation when considered that technology has been defined as a compendium of knowledge and information generated in a 
specific domain, and sistematically used for products and services design, production and marketing; it also includes the proper application of managerial techniques (Delgado Fernández, 2013).

As organizations need more new ideas for adopting technologies, accessing new markets, and implementing business models, so they put pressure on their Research and Development (R\&D) departments (among others) to initiate and implement projects to fulfill these demands (Vicente Oliva, Martínez Sánchez and Berges-Muro, 2015).

According to Gaínza (2006) R\&D projects`' main content is associated to links between science technology and innovation priorities and the problem identified, relevant information searching about products or strategic technologies, as well as bibliography analysis for state of art description.

In health care, a project is recognized as a particularly useful way to introduce innovations, address new challenges or find solutions for problems that the existing procedures and routines do not accommodate. Different types of health projects can be distinguished: research projects, which aim to increase knowledge than can serve as a basis to make "evidence based" decisions; development projects, which involve the development and pre-testing of an intervention to address a particular problem in a particular population or target group; implementation projects, which are concerned with the dissemination and implementation of an existing intervention in a particular target group or population (Santos, Santos, Tavares and Varajão, 2014).

Particularly knowledge, as stated by Bucheli et al and Cantin et al reffered by Back, Kovaleski, and Andrade Junior (2015), is the main engine of growth, then it is necessary to follow the technological advance that happens at high speed and consequently generates a great amount of information. In this sense Technology Watch is considered an important tool for information management.

\subsection{Technology watch and associated topics}

Technology watch is a very relevant topic, given the increasing importance of knowledge in today's economic environment since it responds to systemic changes, temporary competitive advantage, faster decision-making, products and services with lower lifecycles and new forms to compete and interact between actors in the world (Acosta Prado, Mojica Sastoque, Linares Salazar and Ortegon Torres, 2015). 
Jürgens (2017) defined it as a methodology for organisations to systematically analyze technical information in a continuous way in order to gain insight and competitive advantage in a specific technical domain. This definition is not far different from the concept exposed by UNE 166006:2011 (AENOR, 2011).

Many terms have been related to TW:

- Strategic watch: information based process by which the company collect, process and share information in order to reduce future threaths and take advantage of ongoing opportunities. It considers three dimensions (concurrent, comercial and technological watch) to impact on innovation capability (Hourenatou and Zangai Ranbo, 2020).

- Competitive intelligence (foresight and monitoring of data, information and knowledge, as well as filtering, interpretation and value generation for decision making and competitiveness (Pomim Valentim, Ferreira Lenzi, Nogueira Cervamtes, Leão de Carvalho, Dominguez Garcia, Catarino and Tomaél, 2003). Giacomin Menezes and Fernandes De Muylder (2020) design an analysis model that proposes competitive intelligence's contribution to organizational innovation and performance.

Technology Watch is being considered and increasingly used as a tool or the first step into adopting competitive intelligence (Medina Nogueira, 2016); in fact, authors combined both terms: technology watch and strategic intelligence (Palop and Vicente, 1999).

Back et al. (2015) referred that TW of environment favours scientific and technological information management since this process emphasizes on planning, direction, control and coordination of the development and implementation of information system.

To reinforce this idea, we asume the statement of Castiglioni and Adam (2018) around how important is the strategic management of scientific and technological information to innovate and survive in the actual complex and changing environment, what makes TW an essential tool to detect opportunities of technological innovation and new ideas to facilitate improvements in processes, products and services in organizations.

Zárraga-Rodríguez and Álvarez (2016) analyses 25 practices around the use and management of information. One of the studied perspectives was the information management and authors related it to competitive and technology surveillance; systematic information gathering from the environment and the inner workings; ensuring availability of information for stakeholders as needed; data transformation into useful information that can be used for 
decision making; having updated databases so as to ensure that people are using the best information available; distribution and exchange of information and the scope covered.

\subsection{Quality management. Relations with research and knowledge and general issues for health care}

Trying to denote the pecualiarities of quality improvements projects and research, Kumar, Nesbitt and Bakkum-Gamez (2019) refer that while research generates new, generalizable knowledge, quality improvement in healthcare is the translation of existing knowledge, generated initially by research, into clinical practice with the goal of improving the quality of health care in specific populations.

Zárraga-Rodríguez and Álvarez (2016) acknowledge Total Quality Management (TQM) as information-intensive management model, thus a company with a TQM model should manage and use information effectively and with excellence.

As stated by Kim, Gaukler and Lee (2016) healthcare quality is a major driver of innovation, growth, and competitiveness. Healthcare quality and its relevant associated businesses, particularly from a managerial perspective, are a key source of business dynamism, innovation, and improvements in the social ecosystem. Through relevant studies the authors examine the relations between quality of care, knowledge and innovation.

Well defined protocols following standard operating procedures and continually trained staff are the internal measures to control quality, and they are considered as frequent tools to continually improve the effectiveness of quality management system (Aggarwal, Aeran and Rathee, 2019).

Protocols in clinical practice being considered as a result indicator (Torres Andrade et al., 2016); they are the result of a health problem definition and research statement and are based on the principle of providing scientific validity to the standardization of clinical and care processes (Artalejo and Ortún Rubio, 1990; Torres Andrade et al., 2016).

Chan, Tetzlaff, Altman, Laupacis, Gøtzsche, Krle a-Jerić, Hrobjartsson, Mann, Dickersin, Berlin, Dore, Parulekar, Summerskill, Groves, Schulz, Sox, Rockhold, Rennie and Moher (2015) add that evidence based recommendations are key to protocols formulation and therefore they suggest to accomplish thoroughly research studies on benefits and adverse events (published and unpublished) in antecedent phase. Then, with no doubt, research, development, innovation and quality management are useful managerial tools for healthcare improvement, with common bases on information management and knowledge. 


\section{Methodology}

A non experimental study was structured that covers three phases which are shown as follows:

Phase I Prospective study

There were key elements identified to local Research, Technology and Innovation (RTI) in health sector based on:

1) Relevant bibliography analysis that covers the following sequence:

- Search strategy setting: combination of terms "innovation", "technological innovation", "scientific research", “innovation", "quality" or "quality management", "innovation system", "health" and "Cuba"; sources and data bases listing (Google Scholar, Scielo and Science Direct); definition of three search criteria, that is i) title, abstract and keywords, ii) research or original publications, Master and PHD tesis, iii) a five year time frame (2014- 2019).

- Information collecting and filtering: information search was carried out and documents were exported to Endnote. Information gathered was analysed according to duplicates finding and elimination of papers not related to the research área; the latter was aided by an examination of title and abstract

- Literature review. After selecting the texts, there were identified relevant and most frequent variables associated to science and innovation systems, particularly in health care sector.

2) Definition of relevant variables to Research Technology and Innovation development in local health sector whereby there were firstly listed all possible factors that describe RTI with the aid of documents and working reports examination, brainstorming sessions with science and technological innovation specialists and a structured interview to a 20 years experienced director in science and innovation in medical sciences; secondly it was organized a prospective workshop with specialists from Science, Technology and Environment Office, medical university, and health care institutions, and attendants selected the most important topics and were asked to optionally propose additional themes not previously considered. Finally, experts analyzed the direct influence among variables and that information was processed with the aid of MICMAC software, that produced the key variables as the most influencing and dependent (Acosta Valera, 2018). 
Phase II Variables appraissal and improvement strategy

Those key variables' behaviour were assessed based on: reports reviews, science and technology indicators analysis and trends, and an online questionaire sent to four specialists in charge of training and learning activities as well as three scientific board presidents from the most important healthcare institutions located in the city. The online questionaire consisted on six questions that investigated: if research projects are sistematically evaluated; what issues are considered when the project is evaluated; if the hospital update protocols and CPGs; what is the frequency of evaluation of protocols and CPGs; if scientific information from prestigious data bases is used for projects and protocols; and finally what are the most frequent problems affecting protocols and CPGs' design.

The main flaws and limitations to strategic sucess of the RTI system came up from this analysis. This was the starting point to establish the improvement strategy, supported by external and internal information and knowledge management actions.

Phase III Improvement strategy implementation

To implement the actions, it was adopted the UNE 166006:2011 approach for technology watch development (AENOR, 2011):

Information needs definition: there was a questionaire designed (as shown in table 1) aiming to identify informational needs according to two interest groups: academic and healthcare professionals and researchers working in R\&D\&i projects. 
Table 1 - Questionaire for informational needs

\begin{tabular}{|c|c|}
\hline Interest group & Information requested \\
\hline $\begin{array}{l}\text { Academic and } \\
\text { Healthcare } \\
\text { professionals }\end{array}$ & 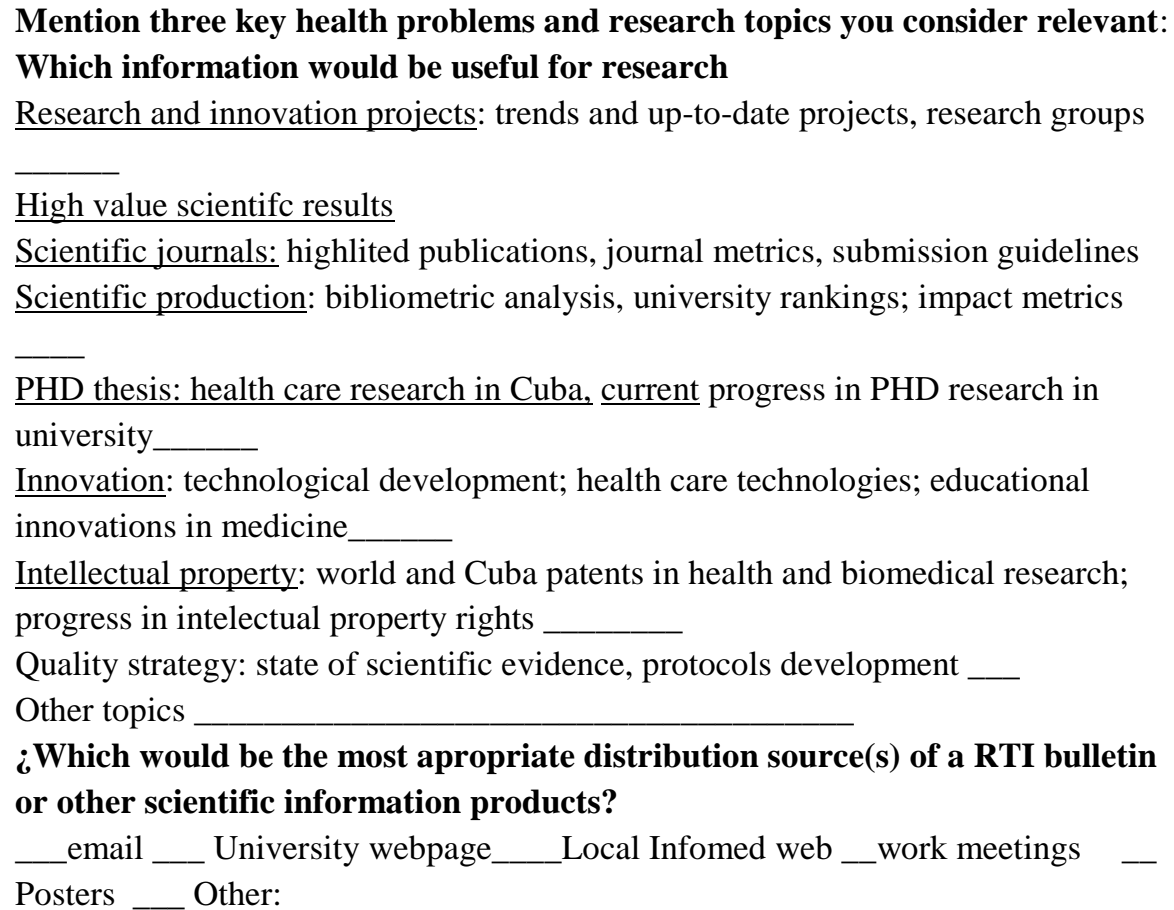 \\
\hline $\begin{array}{l}\text { Researchers in } \\
\text { R\&D\&i projects }\end{array}$ & $\begin{array}{l}\text { Information requested: } \\
\text { Key words } \\
\text { Brief search description } \\
\text { Output format } \\
\text { Time frame of scientific information }\end{array}$ \\
\hline
\end{tabular}

Source: Authors.

Technology watch scheme that consists of devising, according to informational needs analysis, the relevant topics to monitor, key factors to watch; information sources and products to generate; and a chekclist designed so as to implement quality audits focused on identification of critical areas, scientific information searching to support clinical service protocolization and clinical guidelines formulation.

Information seeking, adquiring and processing that comprehends:

a) The evaluation of appropriate search routes and selection of specialized information services according to complexity and nature of the topic to seek;

b) Documents search, recovery and selection for analysis: there were defined the search and criteria strategy, the last consisting of the terms allocated in title, abstract and keywords, range of year; and there were selected relevant documents according to Negri Pagani, Kovaleski, \& Martins de Resende (2018) approach as follows: for each document was determined a) impact factor according to Scopus CiteScore 
metric; and number of citations based on Google Scholar). InOrdinatio index calculation, based on the expression (1)

(1) InOrdinatio $=\left(\frac{I F}{1000}\right)+(\alpha *(10-($ Researchyear - PublishYear $)))+C i$

IF stands for impact factor, $\alpha$ represents a weighting factor ranging from 1 to 10 and it is assigned by the researcher, "Research Year" is the period of study, "Publish Year" refers to the year the article was published and $\mathrm{Ci}$ the number of citations to the document.

b) documents ranking according to InOrdinatio index, the most relevant would have the higher InOrdinatio index.

c) Bibliometric studies that were supported by number of documents produced, articles per year, and co-word analysis.

Information and knowledge sharing: according to preceding actions it was devised a Research Technology and Innovation Bulletin and other information products according to informational needs suggested by users.

\section{Results}

\subsection{Prospective study}

Each stage of phase I was relevant to identify determinant variables to prospective development of health RTI system (Table 2).

Table 2 - Key variables analysis in Health Research Innovation and Technology system

\begin{tabular}{lll}
\hline Phase I & Results \\
\hline $\begin{array}{l}\text { Bibliographic } \begin{array}{l}\text { Documents and } \\
\text { reports analysis }\end{array} \\
\text { review, } \\
\text { working }\end{array}$ & $\begin{array}{l}\text { Review of 24 research articles, six PHD thesis, 15 Master thesis, evaluation } \\
\text { and accreditation manuals, Ministry of Public Health's policy and strategy, and } \\
\text { Research Technology and Innovation reports from years 2013 up to 2018; 56 } \\
\text { related variables were primarily extracted }\end{array}$ \\
\hline Brainstorming & $\begin{array}{l}\text { After eliminating duplicates and variables not directly related to the study, 27 } \\
\text { variables were proposed by specialists; nineteen of them were very similar to } \\
\text { those extracted from bibliography and reports examination }\end{array}$ \\
\hline Structured interview & $\begin{array}{l}\text { The information provided by the interviewed matched with the variables } \\
\text { already selected; they besides proposed the addition of nine topics }\end{array}$ \\
\hline Prospective workshop & $\begin{array}{l}\text { In general 35 variables were evaluated and proposed by workshop attendants } \\
\text { as important issues in RTI in local health system }\end{array}$ \\
\hline $\begin{array}{l}\text { Experts and MICMAC } \\
\text { analysis }\end{array}$ & $\begin{array}{l}\text { Ten variables, out of previous 35, were considered as key ones } \\
\text { Source Authors. }\end{array}$ \\
\hline
\end{tabular}

Source: Authors. 
Figure 1 shows ten key variables for RTI prospective development, grouped in two general themes: Rersearch, development and innovatin and quality management.

Figure 1 - Key variables selected

\section{Research Development and Innovation}

Research management based on projects

Basic and applied research increase

Research topics priorization

Research development and innovation projects formulation

R\&D\&i compliance to reesearch priorities

Technological intensity of innovation

Source: Authors.

\subsection{Variables evaluation and definition of improvement strategy}

Table 3 shows the gap between total number of $R \& D$ projects and Innovation based projects in a period of four years

Table 3 - Innovation projects versus total number of projects

\begin{tabular}{lllll}
\hline Project category/year & 2015 & 2016 & 2017 & 2018 \\
\hline Total number of projects & 113 & 112 & 91 & 113 \\
\hline Total number of Innovation projects & 48 & 68 & 53 & 2 \\
\hline
\end{tabular}

Source: Research data.

There is a clear predominance of research over innovation projects whose number abruptly decreased in 2018. Additionaly the outputs of research in similar timeframe were examined (Figure 2). 
Figure $2-R \& D$ outputs generated from projects development

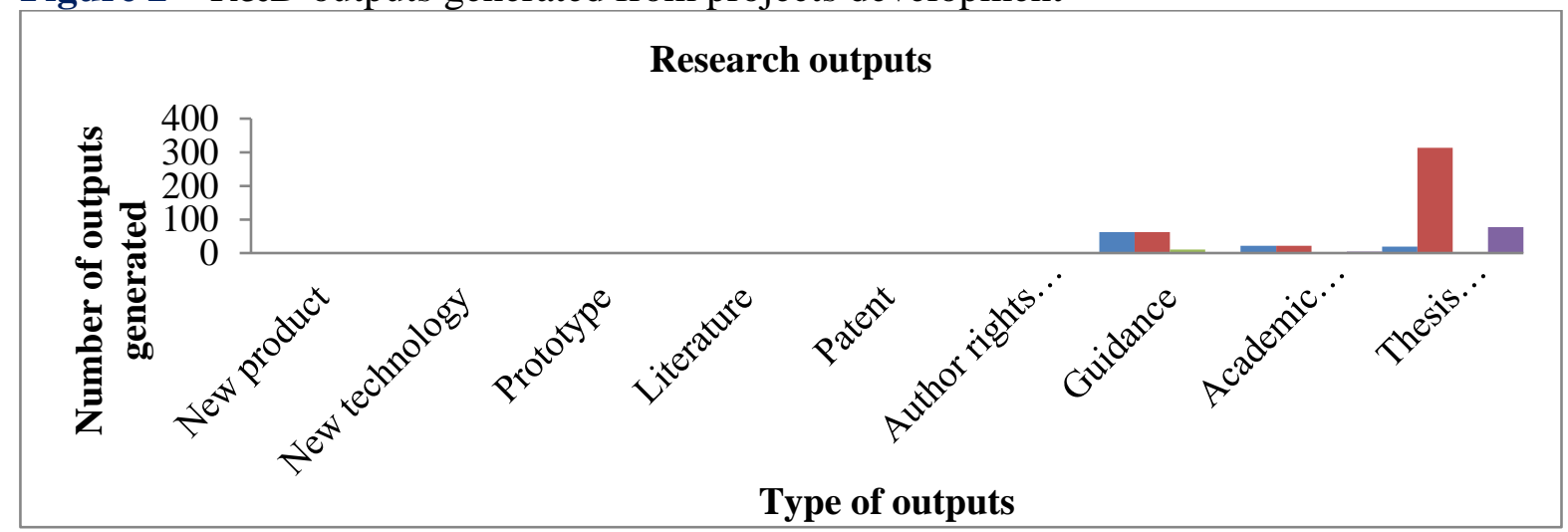

Source: Research data.

The main outpouts reported were asociated to academic materials and guidance as well as specialty thesis. As for the main benefits generated during these years, figure 3 shows that social based benefits are predominant though they decreased in 2017-2018.

Figure 3 - Main benefits generated through R\&D projects

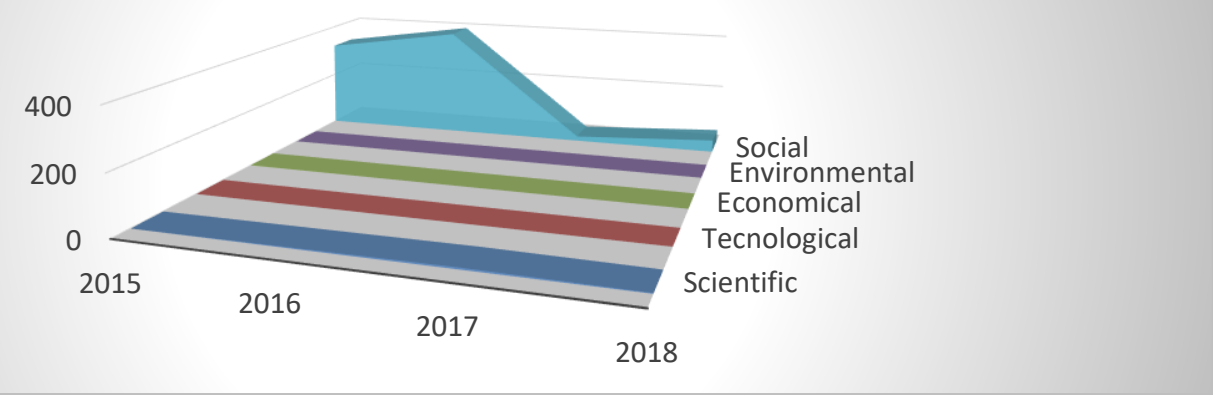

Source: Research data.

Projects analysis from table 3, figures 2 and 3 show gradual low value's results being generated from research and development with low focus on technology and innovative based outputs.

A review of protocols and clinical practice guidelines in five hospitals of the province revealed on one hand that services not using protocols or clinical guidelines still remain and, on the other hand there are design limitations in existing ones (Table 4). 
Table 4 - Protocols and CPGs evaluation in the province' hospitals

\begin{tabular}{llrlrlr}
\hline Institution & $\begin{array}{l}\text { Protocolled Services } \\
\text { (representing percentage out } \\
\text { of total services) }\end{array}$ & $\begin{array}{l}\text { Total number } \\
\text { of protocols }\end{array}$ & $\begin{array}{l}\text { Protocols and } \\
\text { CPGs with } \\
\text { appropriate } \\
\text { design }\end{array}$ & $\begin{array}{l}\text { Protocols and } \\
\text { CPGs with } \\
\text { design } \\
\text { limitations }\end{array}$ \\
\hline Hospital I & 47 & 136 & 103 & 33 \\
\hline Hospital II & 63 & 40 & 14 & 40 \\
\hline Hospital III & 100 & 116 & 43 & 102 \\
\hline Hospital IV & 100 & 43 & 0 & 135 \\
\hline Hospital V & 100 & 135 & & \\
\hline
\end{tabular}

Source: Research data.

Use of protocols and CPG is yet to become a solid instrument for quality of care, as shown in table 4, considering that there still are services with low presence and systematic use and updating of these tools.

The electronic questionaire confirmed the problems revealed above as follows:

- Projects: the main causes for projects rejection are problem setting and scientific contribution, reference update, alignment to research priorities.

- Protocols: most frequent failures are associated to design, research methodology used (lack of skills to problem, objectives, scientific evidence referenced).

The three most frequent non conformities revealed by interviews to specialists and internal audits reports pointed out to: 1) protocols not structured in the standard format, 2) non existence of adherence guide nor evaluation scale and 3) lack of upgrading.

In summary, the former diagnosis pointed out limitations in R\&D\&i projects design and impacts, quality of service delivery and hospital performance due to difficulties in projects, protocols and CPGs design and implementation. These limitations are mainly relying on non existing mechanisms to systematically analyze evidence, research and technological trends, to process relevant scientific information either from comprehensive and updated literature review as from other sources of information like patents, and afterward generate valuable knowledge that help producing better and innovative results and valid recommendations to improve clinical care.

Therefore the improvement strategy formulated was the adoption of knowledge and information based actions to foster research, innovation and quality, consisting of: a) monitoring and information search system supported by information needs evaluation; b) Information and knowledge based actions: research priorities definition as a way to asign strategic resources to projects that prove to have potential to solve main health problems; 
managing projects design and implementation based on information and knowledge study; investigating research fields and scientific evidence on quality of health care services protocols and clinical practice guidelines; Creation and sistematic use of information based products for knowledge sharing to health managers, professionals, researchers and teachers.

\subsection{Improvement strategy implementation}

\subsubsection{Main information needs and monitoring system}

Considering that trends, scientific production analysis, journals, research, technology and patents in biomedical research and protocols and CPG up-to-date were the most frequent type of information revealed by academic and healthcare professionals, the table 5 summarizes the scheme adopted for technology watch.

Table 5 - Scheme for technology watch

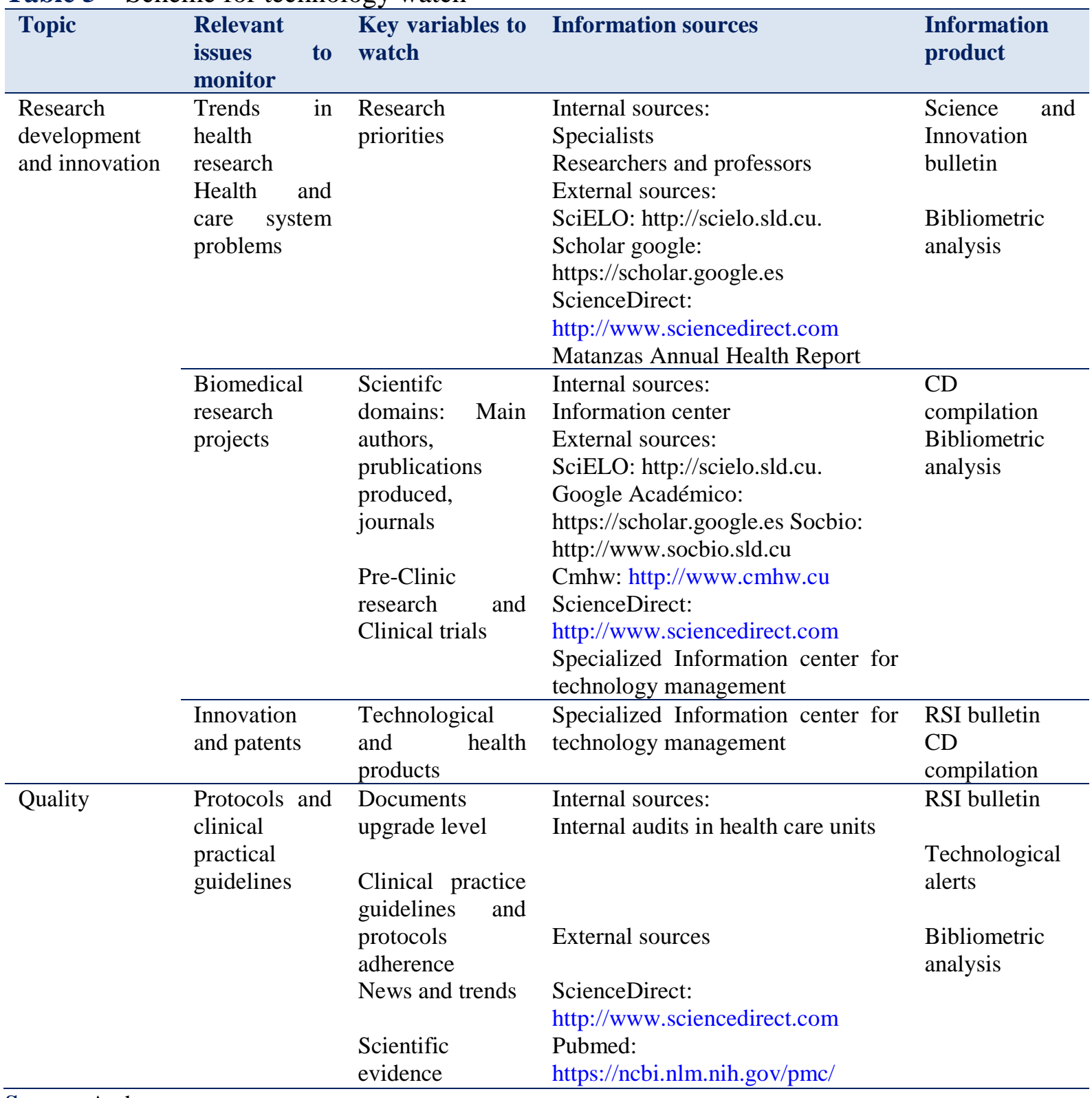

Source: Authors. 
A checklist was designed to support quality audits to protocols and clinical guidelines documentation based on organizational, methodological and scientific evidence issues (Table $6)$.

Table 6 - Checklist designed for quality audits on protocols and guidelines

\begin{tabular}{l}
\hline Documentation item to review \\
\hline Are there sufficient protocols and clinical guidelines to support quality improvement in \\
hospital services? \\
\hline The procedures and protocols accomplished the established requirements (format, \\
adherence guideline and evaluation scale) \\
\hline Is the scientific evidence and information available? \\
\hline Is an explicit notification on changes, upgrading and documents revision registered? \\
\hline Are external documents under control? \\
\hline Is a valid copy of all legal documents preserved? \\
\hline Are Information search and monitoring methods used? \\
\hline Is there access to legal documents?
\end{tabular}

Source: Authors.

\subsubsection{Information and knowledge based actions}

The information adquisition and processing supported the following improvement actions:

- Research priorities setting

Trends and health care problems analysis resulted in the establishment of priorities for research technology and innovation in the province. Out of 353 documents were downloaded; the revealed topics were health administration (166 papers); Maternal and child health (55); Epidemiology and social detarminants (53); Innovation, Informatics and health quality (18); Cancer (17); Knowledge management, Human Capital Training (17); Primary Care (13); Natural and traditional medicine, Farmacology (13); Biomedical research (11); Aging (6); Integrative, translational and precision medicine (4). The first 11 subjects were very similar to the province main health problems; as for the latter in spite of being apparently recent is aknowledged as a growing scientific field. This implied the addition of new research therm considering university's capabilities (technological and knowledge-based) to conduct research development and innovation projects in this area. 
Consequently the research priorities set were as follows: a) Maternal and child health; b) Epidemiology and communicable diseases; c) Mortality and non communicable diseases; d) Aging; e) Psycosocial research; f) Biomedical research and Natural and Traditional medicine; g) Health administration, efficiency quality and innovation for health services; h) Technology information applications for health and training; i) Training and development; j) Integrative medicine.

- Projects design and implementation based on information and knowledge study Table 7 shows the activities adopted to support and add value to projects design and implementation with the aid of information and knowledge analysis.

Table 7 - Information and knowledge based activities to support projects design and implementation

\begin{tabular}{|c|c|c|}
\hline $\begin{array}{l}\text { Project codification/research } \\
\text { priority covered }\end{array}$ & $\begin{array}{l}\text { Life cycle stage of } \\
\text { project }\end{array}$ & Activities \\
\hline I122MT929/Biomedical research & Implementation & $\begin{array}{l}\text { Evaluation of the most relevant journals and } \\
\text { authors and hence appropriate scientifc } \\
\text { information sources and collaboration strategies }\end{array}$ \\
\hline P122MT967/Biomedical research & Design & $\begin{array}{l}\text { Bibliographic review on the theme. Useful to } \\
\text { devise a comprehensive state of the art and } \\
\text { support research problem statement. Analysis of } \\
\text { most relevant journals authors and approriate } \\
\text { scientific information sources }\end{array}$ \\
\hline P122MT995/Integrative medicine & Design & $\begin{array}{l}\text { Bibliographic and patent review on the theme. } \\
\text { Identification of trends, patent analysis and main } \\
\text { technological fields }\end{array}$ \\
\hline $\begin{array}{l}\text { I122MT993/Quality and } \\
\text { innovation for health services }\end{array}$ & Implementation & $\begin{array}{l}\text { Intellectual property study; feasibility appraisal to } \\
\text { evaluate possible patent strategy for product } \\
\text { under design and technology assessment }\end{array}$ \\
\hline $\begin{array}{l}\text { I122MT1035/ Quality and } \\
\text { innovation for health services }\end{array}$ & Design & $\begin{array}{l}\text { Technology assessment and analysis to support } \\
\text { the design of the innovation project }\end{array}$ \\
\hline
\end{tabular}

Source: Authors.

- Investigating research fields and scientific evidence on quality of health care services protocols and clinical practice guidelines

Figure 4 shows the results of the theme search in scopus, in terms of articles published per year associated to the topics: Quality and protocol and health (figure 4a); health care quality and clinical practice or clinical guideline or clinical pathway (figure $4 b$ ); health care quality and scientific evidence or evidence based or evidence based medicine or evidence based practice or knowledge based practice (figure 4c). 
Figure 4 -Theme search in Scopus for quality terms

Total number of documents: 35917

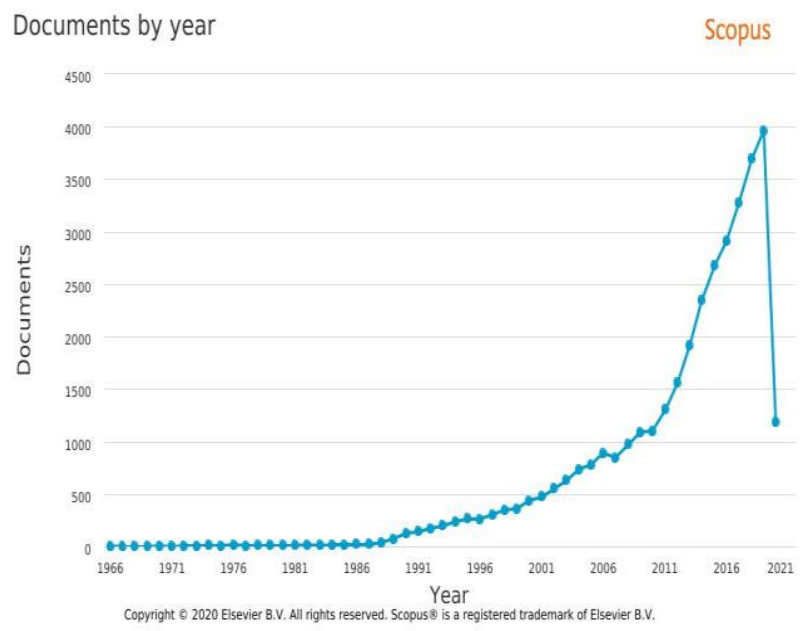

Figure $4 \mathrm{a}$
Total number of documents: 6123

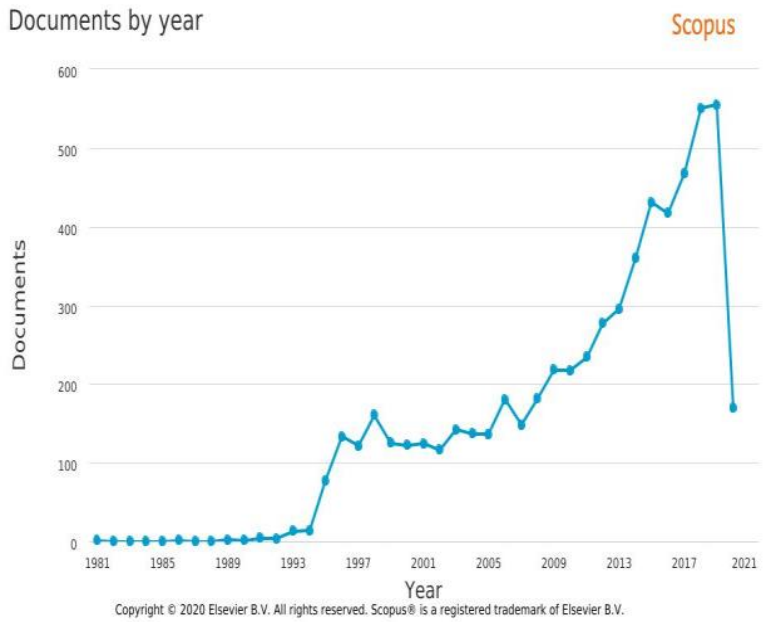

Figure $4 b$

Total number of documents: 2193

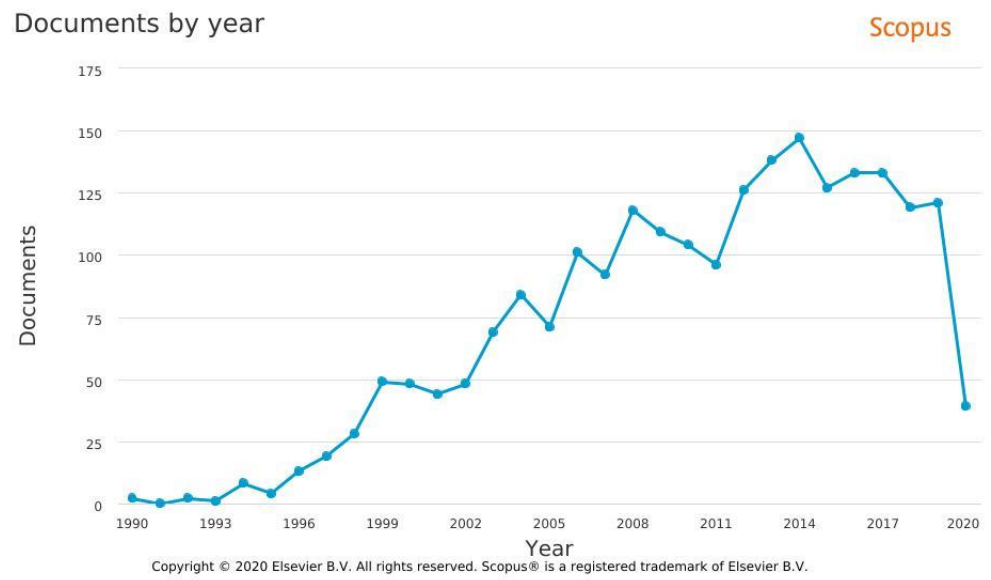

Figure 4c

Source: Research data.

This figure shows how research production have increased with similar tendency for all the topics, in the last 20 years; and also coincidentaly, from 2016 and on, almost all themes (except the third with low numbers in the last two years) reached the highest numbers, which could be an indication of relevance and level of update on the subject. Then there were explored number of documents in other databases in the last five years which is shown in table 8 . 
Table 8 - Results of general search strategy on other databases

\begin{tabular}{lccccc}
\hline Topics & Springer & Emerald & $\begin{array}{c}\text { Taylor } \\
\text { and } \\
\text { Francis }\end{array}$ & Elsevier & Pubmed \\
\hline Quality and protocol and health & 189522 & 2000 & 33945 & 58541 & 90 \\
\hline $\begin{array}{l}\text { health care quality and clinical } \\
\text { practice or clinical guideline or } \\
\text { clinical pathway }\end{array}$ & 191728 & 6000 & 6792 & 58659 & 634 \\
\hline $\begin{array}{l}\text { health care quality and scientific } \\
\text { evidence or evidence based or } \\
\text { evidence based medicine or } \\
\text { evidence based practice or } \\
\text { knowledge based practice }\end{array}$ & & & & & \\
\hline \begin{tabular}{l} 
Source: Research data. \\
\hline
\end{tabular}
\end{tabular}

These imply that there is a considerable amount of papers around the topic. Nonetheless, Springer and Elsevier turn out to be the most recommended databases when studying the first two search strategies; while Taylor and Francis and Springer are valuable suggestions for looking up on the third search strategy.

After recovering 300 documents, 128 documents were obtained when eliminating duplicates; the examination of abstracts resulted in further elimination of ninety papers not directly related to the topic. Then the analysis focused on 60 articles.

With the aplication of InOrdinatio, 27 documents were finally selected. Weighting was done according to recency of papers, then 10 points were assigned to papers published in the last 5 years; publications from prior periods down to a 10 years time frame were weighted on 9 and prior to 10 years time frame papers received 8 points (Table 9).

Table 9 - Documents selection according to InOrdinatio index

\begin{tabular}{|c|c|c|c|}
\hline Selected articles & Journal & $\begin{array}{l}\text { Publication } \\
\text { year }\end{array}$ & InOrdinatio \\
\hline $\begin{array}{l}\text { Progress in evidence-based medicine: a quarter century } \\
\text { on }\end{array}$ & The Lancet & 2017 & 326 \\
\hline $\begin{array}{l}\text { Transforming evidence generation to support health } \\
\text { and health care decisions }\end{array}$ & $\begin{array}{l}\text { New England } \\
\text { Journal of Medicine }\end{array}$ & 2016 & 184 \\
\hline $\begin{array}{l}\text { Modern clinical research: How rapid learning health } \\
\text { care and cohort multiple randomised clinical trials } \\
\text { complement traditional evidence based medicine. }\end{array}$ & Acta Oncologica & 2015 & 149 \\
\hline $\begin{array}{l}\text { Effect of Published Scientific Evidence on Glycemic } \\
\text { Control in Adult Intensive Care Units }\end{array}$ & JAMA Intern Med & 2015 & 146 \\
\hline Nursing perception of patient safety culture & $\begin{array}{l}\text { Ciencia y } \\
\text { Enfermería }\end{array}$ & 2013 & 131 \\
\hline $\begin{array}{l}\text { Translating knowledge on best practice into improving } \\
\text { quality of RRT care: a systematic review of } \\
\text { implementation strategies. }\end{array}$ & $\begin{array}{l}\text { Kidney } \\
\text { International }\end{array}$ & 2011 & 111 \\
\hline $\begin{array}{l}\text { Developing a framework to guide the de-adoption of } \\
\text { low-value clinical practices in acute care medicine: a } \\
\text { study protocol. }\end{array}$ & $\begin{array}{l}\text { BMC Health Serv } \\
\text { Res }\end{array}$ & 2017 & 109 \\
\hline $\begin{array}{l}\text { Safety and quality of maternal and neonatal pathway: } \\
\text { A pilot study on the childbirth checklist in } 9 \text { Italian }\end{array}$ & $\begin{array}{l}\text { Procedia } \\
\text { Manufacturing }\end{array}$ & 2015 & 108 \\
\hline
\end{tabular}




\begin{tabular}{|c|c|c|c|}
\hline $\begin{array}{l}\text { Selective Dissemination of Clinical Guidelines in } \\
\text { Healthcare Communities }\end{array}$ & $\begin{array}{l}\text { IEEE International } \\
\text { Conference on } \\
\text { Industrial } \\
\text { Engineering } \\
\text { Management }\end{array}$ & 2015 & $\begin{array}{r}\text { (conclusion) } \\
102\end{array}$ \\
\hline $\begin{array}{l}\text { Quality and compliance with Clinical Practice } \\
\text { Guidelines of Chronic Noncommunicable } \\
\text { Diseases in primary care. }\end{array}$ & $\begin{array}{l}\text { Salud pública de } \\
\text { México }\end{array}$ & 2017 & 101 \\
\hline $\begin{array}{l}\text { Protocol: Using N-of- } 1 \text { tests to identify responders to } \\
\text { melatonin for sleep disturbance in Parkinson's disease }\end{array}$ & $\begin{array}{l}\text { Contemporary } \\
\text { Clinical Trials } \\
\text { Communications }\end{array}$ & 2019 & 101 \\
\hline Management protocols for chronic heart failure in India & $\begin{array}{l}\text { Indian Heart } \\
\text { Journal }\end{array}$ & 2018 & 101 \\
\hline $\begin{array}{l}\text { Standardizing hypertension management in a primary } \\
\text { care setting in India through a protocol based model }\end{array}$ & $\begin{array}{l}\text { Indian Heart } \\
\text { Journal }\end{array}$ & 2019 & 101 \\
\hline $\begin{array}{l}\text { Evidence-based practice: beliefs, attitudes, knowledge, } \\
\text { and skills among Colombian physical therapists }\end{array}$ & Colombia Médica & 2015 & 98 \\
\hline $\begin{array}{l}\text { Assessment of evidence and quality of clinical practice } \\
\text { guidelines } \\
\text { on deterioration of skin integrity: ulcers and chronic } \\
\text { wounds }\end{array}$ & $\begin{array}{l}\text { An. Sist. Sanit. } \\
\text { Navar. }\end{array}$ & 2016 & 94 \\
\hline $\begin{array}{l}\text { A Scoping Review to Map Empirical Evidence } \\
\text { Regarding Key Domains and Questions in the Clinical } \\
\text { Pathway of Delirium in Palliative Care }\end{array}$ & $\begin{array}{l}\text { Journal of pain and } \\
\text { symptom } \\
\text { management }\end{array}$ & 2019 & 93 \\
\hline $\begin{array}{l}\text { An ontology-based approach to patient follow-up } \\
\text { assessment for continuous and personalized chronic } \\
\text { disease management }\end{array}$ & $\begin{array}{l}\text { Journal of } \\
\text { Biomedical } \\
\text { Informatics } \\
\end{array}$ & 2017 & 93 \\
\hline $\begin{array}{l}\text { Evidence-based medicine: A data-driven approach to } \\
\text { lean healthcare operations }\end{array}$ & $\begin{array}{l}\text { International } \\
\text { Journal of } \\
\text { Healthcare } \\
\text { Management } \\
\end{array}$ & 2019 & 92 \\
\hline $\begin{array}{l}\text { Hospital-based intervention to reduce tPA } \\
\text { administration time }\end{array}$ & $\begin{array}{l}\text { Interdisciplinary } \\
\text { Neurosurgery }\end{array}$ & 2019 & 91 \\
\hline $\begin{array}{l}\text { Efficacy of a transdiagnostic, video-based online } \\
\text { program for reducing depression, anxiety, and suicidal } \\
\text { ideation in adults: Protocol for a randomised controlled } \\
\text { trial }\end{array}$ & $\begin{array}{l}\text { Contemporary } \\
\text { Clinical Trials } \\
\text { Communications }\end{array}$ & 2019 & 90 \\
\hline $\begin{array}{l}\text { Non-randomized comparative study on the efficacy of } \\
\text { a trauma protocol in the emergency department }\end{array}$ & $\begin{array}{l}\text { Chinese Journal of } \\
\text { Traumatology }\end{array}$ & 2019 & 90 \\
\hline $\begin{array}{l}\text { Use of scientific evidence by dentists in Brazil: Room } \\
\text { for improving the evidence-based practice. }\end{array}$ & PLoS ONE & 2018 & 86 \\
\hline $\begin{array}{l}\text { Sustained Reduction and Prevention of Neonatal and } \\
\text { Pediatric Central Line-Associated Bloodstream } \\
\text { Infection Following a Nurse-Driven Quality } \\
\text { Improvement Initiative in a Pediatric Facility }\end{array}$ & $\begin{array}{l}\text { Journal of the } \\
\text { Association for } \\
\text { Vascular Access }\end{array}$ & 2018 & 85 \\
\hline $\begin{array}{l}\text { Implementing Trauma-Informed Care in Primary } \\
\text { Medical Settings: Evidence-Based Rationale and } \\
\text { Approaches }\end{array}$ & $\begin{array}{l}\text { Journal of } \\
\text { Aggression, } \\
\text { Maltreatment \& } \\
\text { Trauma } \\
\end{array}$ & 2019 & 84 \\
\hline $\begin{array}{l}\text { Quality assessment of clinical practice } \\
\text { guidelines of the Chilean explicit guarantees in } \\
\text { healthcare program }\end{array}$ & Rev Med Chile & 2016 & 84 \\
\hline $\begin{array}{l}\text { Enhancing behavioral treatment for women with pelvic } \\
\text { floor disorders: Study protocol for a pilot randomized } \\
\text { controlled trial }\end{array}$ & $\begin{array}{l}\text { Contemporary } \\
\text { Clinical Trials } \\
\text { Communications }\end{array}$ & 2020 & 80 \\
\hline $\begin{array}{l}\text { Effects of evidence-based clinical practice guidelines } \\
\text { in cardiovascular health care quality improvements }\end{array}$ & F1000Research & 2019 & 71 \\
\hline
\end{tabular}

Source: Research data. 
These documents selected were submitted to co-word analysis to denote clinical and care services studied and subjects examined, thus providing scientific information, which can be useful to clinical practitioners, researchers and decision makers.

The main services under analysis in those publications are: Palliative Care; RRT care; non comunicable chronic diseases (cardiovascular; chronic heart failure; personalized chronic disease management; hypertension management); Glycemic Control in Adult Intensive Care Unit; Trauma-Informed Care; dentistry; physical therapy; Neonatal and Pediatric Central LineAssociated Bloodstream Infection; pelvic floor disorders; maternal and neonatal; Parkinson's disease; tPA; depression, anxiety, and suicidal. In an overall examination it is denoted the similarities among these services and the established research priorities for health science and innovation

According to co-ocurrence of keywords, based on title and abstract, it is shown in figure 5 the strongest links among quality, clinical practice guidelines (CPG), medicine and knowledge on one hand, and scientific evidence and publications on the other. That confirms how important is the issue of knowledge and scientific evidence for CPG and protocols, and at the same time how strongly related they are to quality of care.

Figure 5 - Density map on quality of care, protocols search

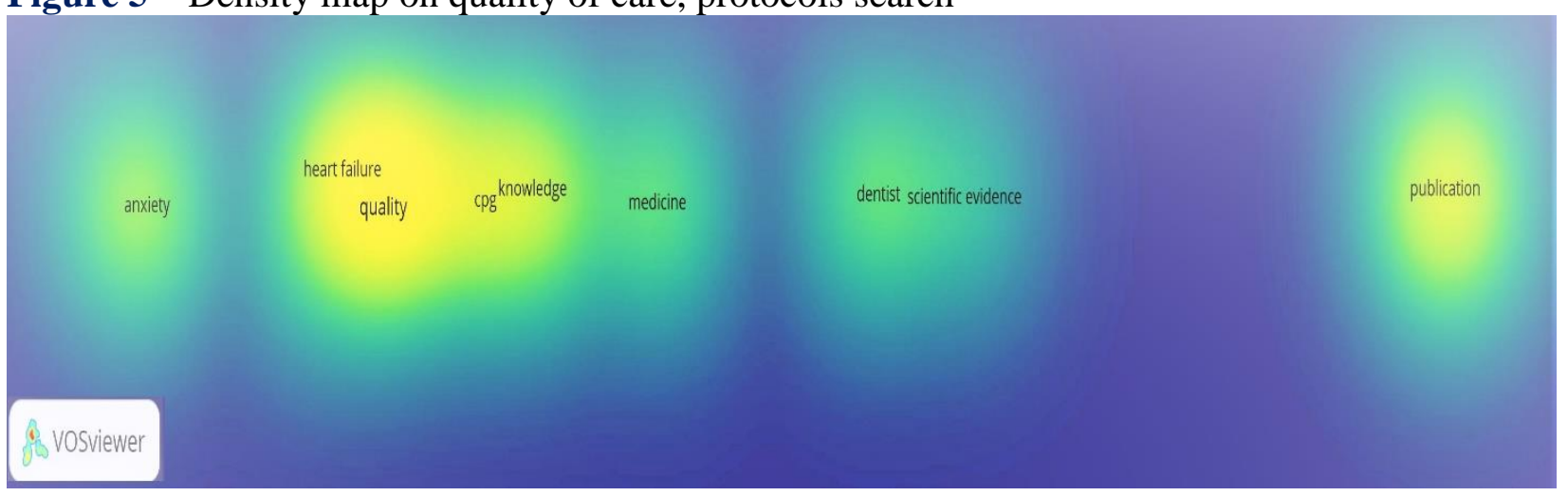

Source: Research data.

All of the above shows the role of scientific information and knowledge on the quality of medical services. Some outlined articles on formulation and assessment of CPG within areas of general medicine, odontology and anxiety studies.

- Information and knowledge sharing

To share information and knowlegde through organization bulletins and other information products were designed. The RTI bulletin had the following features: frequency of distribution (Quaterly); format (Digital and Print); distribution channel (email, institutional 
webpage scientific fórums); content (sections were designed according to priorities and information needs previously established); target users (researchers, managers, students, health professionals).

Other information products created were: CD compilations of relevant articles and patents; and bibliometric studies based reports. In this case they were handed in to individual researchers or research groups.

\section{Discussion}

From table 2 there is a decreasing in innovation projects in disregard to research projects increase

The trend of impacts generated shows no better, and is consequently linked to projects development; there is a predominant number of social impacts while scientific impacts undergone a peak in 2015-2016 due to $\mathrm{PhD}$ tesis being presented, but afterwards it declined again.

When aligment between innovation projects and outputs generated is evaluated, it is evident that a substantial number of scientific results are not transfered into practice as they are no converted into innovations on processes, products or organizational methods. As for protocols it is interesting to note that in spite of being annually reviewed, there still exists a lack of consolidate design and the frequent use of scientific evidence and information in protocols and practice guidelines formulation.

When matching the activities involved in research priority setting, projects design and monitoring and scientific evaluation of quality of care, CPG and protocols, with the concept of TW systems as compilers of information that help to obtain and process all knowledge that might be of interest for an organization; it can be clearly denoted how useful this tool can be to boost strategic development of science innovation and quality of services.

The results obtained by Luque Clavijo et al. (2011) support this statement. Applying TW in SENA, was a determining factor to identify guidelines related to health care and provided cuantitative information about technology for four drills: Nursing, Public Health care, pharmaceutical services and Health care management. It is interesting to notice that quality related topics are emerging as key sub topics in the four studied knowledge areas; and among them: identifying the pressing need for suitable information supply about natural products to improve the quality of life in patients. 
Figure 4 supports the idea that, on one hand quality improvement and standardization of care services is a growing topic in scientific literature and therefore there exists a huge amount of information and knowledge to consider as published evidence for protocols and CPG design and assessment; on the other hand it reveals that along with medicine and nursing being natural perspectives of analysis in this regard, there are other sciences also involved, which provides a multidisciplinarity nature management and improvement decisions on quality of health care.

Then it is clearly acknowledged how important is information acquisition, processing and sharing to foster research and innovation process as well as therapeutic and clinical practices standardization. In this sense there could be shown some literature documents proving this statement:

On one hand Guagliano et al. (2015) work focused on developing a model of TW for the design of market strategies and innovation based on the VTeIE in a cluster of medical technologies. This model promotes the collective and multidisciplinary I\&D\&i, integrating hospitals, universities and institutions, within the science and technology system in Argentina.

There is no doubt universities are the leading components in the foield of TW as supporters in the science, tecnhnology and innovation management and medicine schools are not far apart from this role as in the research of Argote Cusi (2020) where TW was a key factor to value technological capacities which could favor the creation of products database and/or services with commercial and/or patentability potential.

On the other hand, in the work of Achan, Wanzira, Mpimbaza, Tumwine, Namasopo, Nambuya, Serwanga and Nantanda (2020) the surveillance system adopted enhanced the compilation of data and analysis of trends in a timely manner and promoted regular feedback to health workers and the administration. The authors pointed out the use of audits based on available data, supporting organizational planning, changing in practices and considered it an efective instrument in improving professional practice.

Then the audit checklist designed in this article aims to identify areas of improvement concerning the use of protocols and clinical practice guidelines as useful tools for quality of care services. It is important to note that the focus of this analysis is on three dimensions: level of utilization of such tools for quality improvement; use of scientific information, evidence and knowledge for devising and updating; and quality of its design.

The use and flow of information and knowledge have been similarly analysed in two approaches for information and knowledge audit (González Guitián, de Zayas Pérez, and 
Martínez Ríos, 2016) and kowledge management audit (Medina Nogueira, YE, Nogueira Rivera, Medina León, Medina Nogueira, El Assafiri Ojeda and Castillo Zúñiga., 2017). The study of González Guitian and Martínez Ríos (2016) pointed out important directions for strategic planning, training programs development, and specific guidelines for process improvement and quality system implementation in a research center. Meanwhile, the proposal of Medina Nogueira, YE et al. (2017) may contribute to the efficiency and effectiveness of the organization's objectives, based on knowledge management and continuous improvement, so as to ensure the establishment of good practices, as well as the acquisition and conservation of the knowledge; so the audit should respond to questions related to: necessary knowledge to acquire in the process, knowledge organization and dissemination and use.

As for the quality of its design this is just a first approach into adopting very common practices in protocols and CPG appraisal, such as the AGREE (Appraisal of Guidelines, Research and Evaluation) tool, which is widely used to evaluate the quality standard, methodological rigour and transparency of guideline development of CPGs in six qualityrelated domains: scope and purpose, stakeholder involvement, rigor of development, clarity and presentation, applicability, and editorial independence (Chua, Ming, Chang, Santos, Mistry, Silangcruz, Bayley and Koyle 2018; Hou et al., 2019; Shallwani, King, Thomas, Thevenot, De Angelis, Aburub and Brosseau 2019; Yang, Zhang, Tan, Zhang and Zhang, 2019).

The authors discussions and conclussions converged into two interesting issues for this investigation, as they place particular emphasis on: rigor of CPGs as a limitation to improve, considering that it focuses on the methodological process of literature review, evidence gathering and appraisal and recommendations formulation depending on the best available evidence (Chua et al., 2018; Hou et al., 2019); and sistematic review, and sharing of CPGs' evidence and information may help health professionals to access to well-developed and appropriate materials for knowledge interpretation (Shallwani et al., 2019) and to identify gaps that can be improved (Yang et al., 2019).

In fact it is well recognized in literature the relevance of available scientific information and evidence consideration when formulating or evaluating the efficiency of a CPG (Niven, Rubenfeld, Kramer and Stelfox, 2015; Ramírez-Morera, Tristan and Vazquez, 2019) or supporting health care decisions (Califf, Robb, Bindman, Briggs, Collins, Conway, Coster, Cunningham, De Lew and DeSalvo, 2016); but then the dissemination of CPG for health professionals via the use of communication technologies is also a study under examination (De 
Angelis, Davies, King, McEwan, Cavallo, Loew, Wells and Brosseau., 2016; Puustjärvi and Puustjärvi, 2015).

Then it could be said that there are relevant links among quality, knowledge, research as it is shown in density map from co-ocurrence analysis (figure 5) according to a sample of the published articles with highest impact.

The authors assume as limitations that the study might not have applied the audit checklist to empirically confirm its validity, compare its results with the scientific study and literature review. Secondly is not evaluating the impact of this improvement strategy on research results, quality management and decission making and the third lies on the combination of tools used. These, at the same time are future research directions.

\section{Final considerations}

Science and innovation management in health sector faces important challenges that have become priorities nowaday, those being: generation of high impact scientific and technological results that may turn into innovations, as well as the development of a strategy of quality that lies on key goals like those promoting continuous improvement and developing protocols and clinical practice guidelines.

For instance quality management and research and development variables turn out to be the selected key factors for prospective and strategic sucess of local health science and innovation system. The evaluation revealed improvement opportunities related to find, process and use scientific information to identify relevant research, global and regional trends, emergent health technologies and updated evidence that aim to produce R\&D \&i projects and protocols to boost quality of service.

The adoption of TW tools allowed the design of improvements into processes of R\& D projects and quality of care management, and it is based on using and sharing scientific information and knowledge which would eventually provide higher value to research and innovation results as well as scientific evidence to clinical practices and protocols establishment in care services.

There are future directions deriving from this experience, mainly measuring the impact of information and knowledge management into health innovation and quality performance and integrating other tools like data mining, BPM and other TW software. 


\section{References}

Achan, J., Wanzira, H., Mpimbaza, A., Tumwine, D., Namasopo, S., Nambuya, H., Serwanga, A., Nantanda, R. (2020). Improving the quality of neonatal data capture and clinical care at a tertiary-care hospital in Uganda through enhanced surveillance, training and mentorship. Paediatrics and International Child Health, 40(2): 92-104.

Acosta Prado, J. C., Mojica Sastoque, F. J., Linares Salazar, J. H., \& Ortegon Torres, L. G. (2015). A Foresight Study of Department of Bolivar towards 2033. Development, 58(1): 117128.

Acosta Valera, C. (2018). Análisis del desarrollo prospectivo de la Dirección de Ciencia, Innovación y Tecnología de Salud en Matanzas. Unpublished thesis in Industrial Engineering, Universidad de Matanzas, Matanzas, Cuba.

Aggarwal, A., Aeran, H., \& Rathee, M. (2019). Quality management in healthcare: The pivotal desideratum. Journal of Oral Biology and Craniofacial Research, 9(2): 180-182.

Aguirre Ramirez, J. J., Cataño Rojas, J. G., \& Rojas López, M. D. (2013). Análisis prospectivo de oportunidades de negocios basados en vigilancia tecnológica. Revista PUENTE Científica, 7(1), 29-39.

Alfonso Sánchez, I. R., \& Ponjuán Dante, G. (2016). Diseño de un modelo de gestión de conocimiento para entornos virtuales de aprendizaje en salud. Revista Cubana de Información en Ciencias de la Salud, 27(2), 138-153.

Arciénaga Morales, A. A., Nielsen, J., Bacarini, H. A., Martinelli, S. I., Kofuji, S. T., \& García Díaz, J. F. (2018). Technology and Innovation Management in Higher Education-Cases from Latin America and Europe. Administrative Sciences, 8(11), 1-34.

Argote Cusi, M. L. (2020). Identificación de las capacidades tecnológicas de la Fundación Universitaria de Ciencias de la Salud, Colombia. Revista Repertorio de Medicina y Cirugía, 20: $1-14$

Artalejo, F. R., \& Ortún Rubio, V. (1990). Los protocolos clínicos. Med Clin (Barc), 95: 309316.

Back, L., Kovaleski, J. L., \& Andrade Junior, P. P. (2015). Translation of Technological Surveillance as a tool for Information Management: A literature review. J IEEE Latin America Transactions, 13(10): 3505-3510.

Barreneche, J., García, J., Serrano, J., Brand, J., \& Hernández, A. (2015). Improvement of emergency services using technological surveillance and competitive intelligence. Article presented at Pan American Health Care Exchanges (PAHCE 2015), Viña del Mar, Santiago de Chile.

Califf, R. M., Robb, M. A., Bindman, A. B., Briggs, J. P., Collins, F. S., Conway, P. H., Coster, T. S., Cunningham, F. E., De Lew, N. and DeSalvo, K. B. (2016). Transforming evidence generation to support health and health care decisions. N Engl J Med, 375(24): 2395-2400. 
Carrillo Zambrano, E., Páez Leal, M. C., Suárez, J. M., \& Luna-González, M. L. (2018). Modelo de vigilancia tecnológica para la gestión de un grupo de investigación en salud. MedUNAB, 21(1): 84-99.

Castiglioni, S. N., \& Adam, C. (2018). Surveillance competences for entrepreneurs: a key factor to boost the number of science-based startups. Article presented at the Proceedings of the 62nd Annual Meeting of the ISSS-2018 Corvallis, OR, USA.

Cerezo-Narváez, A., García-Jurado, D., González-Cruz, M. C., Pastor-Fernández, A., OteroMateo, M., \& Ballesteros-Pérez, P. (2019). Standardizing Innovation Management: An Opportunity for SMEs in the Aerospace Industry. Processes, 7(5): 282.

Cetindamar, D., Phaal, R., \& Probert, D. (2009). Understanding technology management as a dynamic capability: A framework for technology management activities. Technovation, 29: 237-246.

Chan, A.-W., Tetzlaff, J. M., Altman, D. G., Laupacis, A., Gøtzsche, P. C., Krle a-Jerić, K., Hrobjartsson, A., Mann, H., Dickersin K., Berlin, J. A., Dore, C. J., Parulekar, W. R.,. Summerskill, W. S.M., Groves, T., Schulz, K. F., Sox, H. C., Rockhold, F. W. Rennie, D. and Moher, D. (2015). SPIRIT 2013 Statement: defining standard protocol items for clinical trials. Revista Panamericana de Salud Pública, 38(6): 506-514.

Chua, M., Ming, J., Chang, S. J., Santos, J. D., Mistry, N., Silangcruz, J. M., Bayley, M. \& Koyle, M. A. (2018). A critical review of recent clinical practice guidelines for pediatric urinary tract infection. Can Urol Assoc J, 12(4): 112-118.

Colectivo de autores. (2016). Manual de acreditación hospitalaria. La Habana: ECIMED. Editorial Ciencias Médicas.

Comité Central del PCC. (2017). Actualización de los Lineamientos de la Política Económica y Social del Partido y la Revolución para el período 2016-2021. La Habana: Partido Comunista de Cuba.

De Angelis, G., Davies, B., King, J., McEwan, J., Cavallo, S., Loew, L. Wells, G. A. \& Brosseau, L. (2016). Information and Communication Technologies for the Dissemination of Clinical Practice Guidelines to Health Professionals: A Systematic Review. JMIR Med Educ, 2(2): 1-16.

Delgado Fernández, M. (2013). Innovación Materiales docentes del diplomado en dirección y gestión de empresas, Vol. 1- Escuela Superior de Cuadros del Estado y el Gobierno. Cuba.

Elías Dib, J. (2009). Clinical practice guidelines: proposal to improve quality in health care services. Cirugia y cirujanos, 77(2): 87-88.

Gaínza, E. (2006). Innovación de producto. In Faloh Bejerano, R. (ed.), Gestión de la innovación. Una visión actualizada para el contexto Iberoamericano, pp. 102-118, La Habana: Editorial Academia.

García Delgado, B. M., Delgado Fernández, M., \& Infante Abreu, M. B. (2014). Metodología para la generación y gestión del conocimiento para proyectos de I+ D+ i a partir de sus factores críticos. Revista Cubana de Información en Ciencias de la Salud, 25(3): 285-302. 
Gaviria Roa, L. A., Hernández Martínez, H., \& Montiel Ariza, H. (2019). Contextualization of ICT Tools for Technological Surveillance Systems Associated with Innovation Processes. International Journal of Engineering and Technology, 10(6): 1621-1625.

Giacomin Menezes, R., \& Fernandes De Muylder, C. (2020). Inteligência competitiva, inovação e performance: proposta de modelo teórico. Brazilian Journal of Development, 6(1): 657-678.

González Guitián, M. V., de Zayas Pérez, M. R., \& Martínez Ríos, M. (2016). Auditoría integrada de Información + Conocimiento: aplicación en un caso de estudio. Revista General de Información y Documentación, 26(1): 43-64.

Guagliano, M., Massaro, F. G., \& Rodríguez Bianchi, S. (2015). Modelo de Vigilancia Tecnológica e Inteligencia Competitiva aplicado al sector de tecnologías médicas en el territorio de Lomas de Zamora. Article presented at Inovação para além da tecnologia ALTEC 2015, Porto Alegre, Brazil.

Guagliano, M., Villanueva, M., Perez, N., \& Sánchez Rico, A. (2019). Nuevas herramientas para la toma de decisiones: Vigilancia Tecnológica e Inteligencia Estratégica. Revista Abierta de Informática Aplicada, 3(2): 15-22.

Guagliano, M. L., Tornillo, J. E., Pascal, G., \& Massaro, F. G. (2017). Vigilancia Tecnológica e Inteligencia Estratégica aplicada a biofármacos: oportunidades para el desarrollo de nuevos productos de alto valor agregado. Revista Científica, 2(2): 1-17.

Hernández Betancourt, J. (2015). Un acercamiento impostergable del sistema cubano de salud a la calidad. Revista Electrónica Dr. Zoilo E. Marinello Vidaurreta, 38(7): 1-12.

Hernández Nariño, A., López Álvarez, C., Castro Hernández, A., \& Ponce de León Narváez, R. (2019). Diseño de un proyecto para mejorar la gestión de la innovación y la calidad en salud. Uniandes Episteme. Revista digital de Ciencia, Tecnología e Innovación, 6(2): 180193.

Hoffmann, M., Stichele, R. V., Bates, D. W., Björklund, J., Alexander, S., Andersson, M. L., Auraaen, A., Bennie, M., Dahl, M-L., Eiermann, B., Hackl, W., Hammar, T., Hjemdahl, P., Koch, S., Kunnamo, I., Le Louët, H., Panagiotis, P., Rägo, L., Spedding, M., Seidling, H. M., Demner-Fushman, D. \& Gustafsson, L. L. (2020). Guiding principles for the use of knowledge bases and real-world data in clinical decision support systems: report by an international expert workshop at Karolinska Institutet. Expert Review of Clinical Pharmacology, 1-10.

Hou, X., Li, M., He, W., Wang, M., Yan, P., Han, C., Li, H, Cao, L, Zhou, B., Lu, Z., Jia, B., Li, J., Hui, X. \& Li, Y. (2019). Quality assessment of kidney cancer clinical practice guidelines using AGREE II instrument: A critical review. Medicine (Baltimore), 98(40): 19.

Hourenatou, \& Zangai Ranbo, L. T. (2020). Veille Stratégique et Capacité d'innovation des Petites et Moyennes Industries Camerounaises. International Journal of Accounting, Finance, Auditing, Management Economics, 1(1): 14-29. 
Jürgens, B. (2017). Patent bibliometrics and its use for technology watch. Journal of Intelligence Studies in Business, 7(2): 17-26.

Kim, R. H., Gaukler, G. M., \& Lee, C. W. (2016). Improving healthcare quality: A technological and managerial innovation perspective. Technological Forecasting and Social Change, 113: 373-378.

Kumar, A., Nesbitt, K. M., \& Bakkum-Gamez, J. N. (2019). Quality improvement in gynecologic oncology: Current successes and future promise. Gynecologic Oncology, 152(3): 486-491.

Luque Clavijo, A. M., Sepulveda Carrillo, G., \& Cano Urrego, E. (2011). Vigilancia tecnológica para el SENA: propuesta de líneas de investigación aplicada en salud. Servicio Nacional de Aprendizaje (SENA)- Centro de Formación de Talento Humano en Salud Regional Distrito Capital, Colombia.

Mardani, A., Nikoosokhan, S., Moradi, M., \& Doustar, M. (2018). The Relationship Between Knowledge Management and Innovation Performance. Journal of High Technology Management Research, 29: 12-26.

Medina Nogueira, D. (2016). Instrumento metodológico para gestionar el conocimiento mediante el observatorio científico. Unpublished doctoral thesis, Universidad de Matanzas Sede "Camilo Cienfuegos", Matanzas, Cuba.

Medina Nogueira, Y., Nogueira Rivera, D., Medina León, A., Medina Nogueira, D., El Assafiri Ojeda, Y., \& Castillo Zúñiga, V. (2017). Methodolgy for Knowledge Management Audit. Global Journal of Engineering Science and Researches, 4(11): 1-9.

Ministerio de Salud Pública. (2016). Estrategia Nacional de Gestión de la Calidad en el Sector Salud. La Habana: ECIMED.

Negri Pagani, R., Kovaleski, J., \& Martins de Resende, L. (2018). Avanços na composição da Methodi Ordinatio para revisão sistemática de literatura. Ci.Inf., 46(2): 161-187

Niven, D. J., Rubenfeld, G. D., Kramer, A. A., \& Stelfox, H. T. (2015). Effect of published scientific evidence on glycemic control in adult intensive care units. JAMA Intern Med, 175(5): 801-809.

Organisation for Economic Co-operation and Development. (2015). Frascati Manual. Guidelines for collecting and reporting data on research and experimental development. Measurement of scientific, technological and innovation activities. Paris, France: OECD Publishing.

Palop, V., \& Vicente, J. (1999). Vigilancia tecnológica e Inteligencia competitiva. Su potencial para la empresa española. Madrid: Fundación COTEC.

Pérez Sánchez, A., Paredes Esponda, E., León Rodríguez, A., \& Pérez de Hoz, G. (2017). Impacto de la innovación tecnológica en el desarrollo de la salud cubana. Infodir, 24(enerojunio): 41-53. 
Pomim Valentim, M. L., Ferreira Lenzi, L. A., Nogueira Cervamtes, B. M., Leão de Carvalho, E., Dominguez Garcia, H., Catarino, M. E., \& Tomaél, M. I. (2003). O processo de inteligência competitiva em organizações. DataGramaZero - Revista de Ciência da Informação, 4(3): 1-21.

Puustjärvi, J., \& Puustjärvi, L. (2015). Selective dissemination of clinical guidelines in healthcare communities. Article presented at 2015 IEEE International Conference on Industrial Engineering and Engineering Management (IEEM), 706-710.

Ramírez Morera, A., Tristan, M., \& Vazquez, J. C. (2019). Effects of evidence-based clinical practice guidelines in cardiovascular health care quality improvements: A systematic review. F1000Research, 8, 10-41.

Resolución 287. (2019). Reglamento para el Sistema de Programas y Proyectos de Ciencia, Tecnología e Innovación. La Habana: Gaceta Oficial No. 86 Ordinaria de 8 de noviembre de 2019.

Rojo Pérez, N., Valentti Pérez, C., Martínez Trujillo, N., Morales Suárez, I., Martínez Torres, E., Fleitas Estéves, I., Portuondo Sao, M., Torres Rojo, Y., \& Sierra González, V. G. (2018). Ciencia e innovación tecnológica en la salud en Cuba: resultados en problemas seleccionados. Revista Panamericana de Salud Pública, 42(32): 1-11.

Santos, C., Santos, V., Tavares, A., \& Varajão, J. (2014). Project Management Success in Health - The Need of Additional Research in Public Health Projects. Procedia Technology, 16: 1080-1085.

Shallwani, S. M., King, J., Thomas, R., Thevenot, O., De Angelis, G., Aburub, A. S., \& Brosseau, L. (2019). Methodological quality of clinical practice guidelines with physical activity recommendations for people diagnosed with cancer: A systematic critical appraisal using the AGREE II tool. PLoS One, 14(4): 1-16.

Toledo Hernández, A., Portuondo Sao, M., Morales del Rosario, I., Norabuena Canal, M., \& Mejías Sánchez, Y. (2016). Directrices metodológicas para la evaluación de tecnologías sanitarias. Infodir, (23): 1-10.

Torres Andrade, M. C., Alarcón, J., Berthet, A., Cantero, V., Llanquipichún, D., Sáez, D., \& Yáñez, I. (2016). Modelo de certificación de calidad para la gestión del cuidado en hospitales chilenos. Referência-Revista de Enfermagem, 4(9): 65-74.

AENOR (2011). UNE 166006: 2011 Gestión de la I+D+i: Sistema de vigilancia tecnológica e inteligencia competitiva.

van der Veer, S. N., Jager, K. J., Nache, A. M., Richardson, D., Hegarty, J., Couchoud, C., de Keizer, N. F., \& Tomson, C. R. V. (2011). Translating knowledge on best practice into improving quality of RRT care: a systematic review of implementation strategies. Kidney International, 80(10): 1021-1034.

Vargas, E., Duque Beltrán, S., Arévalo Jamaica, A., \& Quintero Vargas, F. (2018). Vigilancia tecnológica e inteligencia competitiva de un desarrollo tecnológico para la detección de Giardia, una innovación en salud. Revista Panaméricana de Salud Publica, 42: 1-8. 
Vicente Oliva, S., Martínez Sánchez, Á., \& Berges-Muro, L. (2015). Research and development project management best practices and absorptive capacity: Empirical evidence from Spanish firms. International Journal of Project Management, 33(8): 1704-1716.

Yang, X., Zhang, A., Tan, Y., Zhang, Z., \& Zhang, J. (2019). Critical appraisal of clinical practice guidelines for the diagnosis and treatment of stress urinary incontinence using AGREE II instrument: a systematic review protocol. BMJ Open, 9(9): 1-4.

Zárraga-Rodríguez, M., \& Álvarez, M. J. (2016). Efficient information-related practices in companies committed to EFQM. The TQM Journal, 28(6): 798-813. 